\title{
The Political Features of the Extradition \\ ${ }^{* 1}$ Kamila D. Shaibakova, ${ }^{2}$ Maria V. Talan \\ ${ }^{1,2}$ Kazan Federal University \\ Email:kamila.shaibakova@gmail.com, Contact: + 79610411555
}

Received: 21st October 2017 Accepted: 16th November 2017, Published: 31st December 2017

\begin{abstract}
This article is devoted to the matters of extradition of the persons who have committed a crime and its political characteristics which complicate the procedure, doing it inefficient and dependent on a political situation in the world. The extradition is one of the most used procedures of the international cooperation. However, its legal regulation still needs improvement. According to requirements, extradition of the person who is pursued for political crimes is forbidden. However, what is political crime still isn't clear. In the legislation of the Russian Federation there is no accurate definition and special rules to define whether crime is crime of political character. In this article various definitions and tests which are used in various jurisdictions are considered. Authors consider that the approach chosen by Germany and Switzerland is the most appropriate as considers not only the act, but also motives and consequences as forming structure of political crime. Authors consider that legislative acceptance of definition or the special test can influence in a due measure reduction of influence of policy by the right in the context of an extradition.
\end{abstract}

Keywords: Extradition, Political Offence, Test, Definition, The Russian Federation.

\section{Introduction}

Nowadays extradition as one of the main instruments of international cooperation is used more frequently. Globalization, flexible visa and border regimes, migration are invoked to be the main reasons for that. Nonetheless, extradition process raises difficulties in the application that makes the process highly inefficient. Extradition claims to be a procedure dependent on the politics. This feature frequently uses by states and individuals to abuse the law and rights. Thus, the main purpose of the article is to consider whether it is possible to improve the surrender of criminals by reducing or eliminating the political elements.

In the article, we considered a variety of definitions of a 'political offence' and tests that are applied by different jurisdictions such as Switzerland, France, the United States and others. We based our reasoning on the case-law, academia, and current politics. In order to draw conclusions, the comparative, systematic and historical methods were applied.

The Russian Federation is advised to incorporate the definition of the 'political offence' in the legislation. Currently, there is neither definition, not the special determining test that could assist authorities. Such definition seems to be a tool for the improvement of the extradition and assist in the reduction of the political influence on the surrender. The elimination of the politics seems to be a premature thought to consider. The example of the European Union that successfully applies the concept of 'mutual trust' and eliminated the 'political offence' exception is a great role model, which would be highly difficult to apply elsewhere, except regional framework.

\section{Methods}

The research question that used in the articles is: "Could the political features of the extradition process be eliminated or reduced?" In order to answer the research question of explanatory nature, we need first of all to operationalize the terms used. The reference to 'political features' means the influence that politics, international relations make to the extradition. The term "eliminate" used in order to research whether it is possible to clearly distinguish between politics and law in the context of the extradition. The assumption from the research question may be made that the absolute elimination of politics is a premature thought. Therefore, we added the term "reduce". In the paper, the terms "extradition" and "surrender" will be used interchangeably. In order to give a background context of the problem, the historical method is applied. Subsequently, the comparative case study method and research design are used considerably in order to understand what the standards that are common in the various jurisdictions. This is a traditional legal research and thus the already existing data was collected using the legal databases and literature. In the article, the variety of different jurisdictions is used. The rationale behind the choice is that the picked jurisdictions developed the specific tests in order to identify the political character of a crime.

\section{Discussion \\ Historical Background}

It is still common in States consider extradition as a matter very close to their sovereignty. Political considerations continue to play an important role in extradition relations between States and in practice may override concerns for the human rights and the principle of legality [1].

The political offence exception was primarily a creation of liberal nations to support those in the fight against tyranny. The French Revolution became a crucial moment in 'political offence' clause. It was the case for Russia, which before French Revolution has law "providing the possibility to extradite even for crime depending with political conviction or for crimes 
which are called in international law as political offences" [2].

After the French Revolution extradition was mostly considered as a legal procedure. Not only liberal states put a 'political offence' clause in the legislature or in the bilateral agreement, but also autocracies created a political offence exception in their laws and treaties because "without it, the liberal states were unwilling to extradite ordinary criminals to them" [3].

\section{Current State of Problem}

In accordance with the European Commission, one of the positive effects of the European Arrest Warrant [hereafter - EAW] is that there is no political involvement as decisions are made by judicial authorities alone. This is a great achievement as a political component frequently makes extradition procedure more complicated. However, it's highly arguable statement, as even if diplomatic channels are excluded from the surrender discussions, political moods always keep in mind.

The most illustrative example is the Edward Snowden case. Edward Snowden is a US national, former Central Intelligence Agency and National Security Agency employee. He disclosed a large number of secret documents about global surveillance programs. On June 21, 2013, US Department of Justice unsealed charges against in accordance with Espionage Act and theft of governmental property crime. On June 23, 2013, Mr. Snowden flew to Moscow, where after a month of remain, he was granted a temporary asylum for a one year with the possibility of prolongation.

The request from the United States was denied by Russian authorities in accordance with "political character of an offence". It shall be mentioned that there is no extradition treaty between Russia and USA, and reciprocity practice is highly controversial. However, after denying the extradition request, the White House Administration said that they "are extremely disappointed that the Russian government would take this step despite our very clear and lawful request" [4] and canceled the scheduled meeting between the two Presidents.

The reason why both governments cannot reconcile on the issue at stake as there is no clear understanding of what is the 'political offence' and how the legal requirements shall work in order to protect both state interests and human rights.

Hence, this case clearly demonstrates how the politically dependent extradition procedure is and how it can influence the political climate in the world.

'Political offence' definitions and test

There is no universal 'political offence' test. Currently, several tests exist that assist in the separation of a political offence from an ordinary one. The classification distinguishes between absolute or relative offence, political incidence test, injured rights test and motive test. We collected aforementioned tests and notions in Table 1.

According to absolute or relative offence test, crimes can be divided into two categories: absolute political crimes which directed against the political organization or the government and contain no elements of a common crime. Relative offences are in se common crimes which are linked to the political offences due to the perpetrator's political purpose or political consequence of a crime [5].

There has never been a precise definition of what constitutes a political offence between states, which has generally led to different interpretations of the term [6]. One of the main complications is that what constitutes a political offence depend largely upon the circumstances of the case [7].

The following are some of the definitions of political offences. Political offences are crimes which are primarily directed against the form of government [8]; political offences are all attempts against the constitution of a government and against sovereignty. Faustin Helie defines the political offence as those "which attack solely the constitution of the nation in its social form essentially variable and the criminality of which is itself dependent on the times and places [9].'In Re Castioni, English court adopted a wellknown definition of Sir James Stephen according to which political offences are those which are "incidental to and form a part of political disturbances [10]."

A French court in the Giovanni Gatti Case reasoned that pure political offences are "those which cause injury the political organism, which is directed against the constitution of the government and against sovereignty, and which trouble the order established by the fundamental laws of the state and distribution of power [11]."

Hence, absolute political offence encompasses no harm to private persons or their interests. Most of the times, the absolute political offences are not difficult to establish and do not raise questions and problems in their application. The difficulties could be found in the context of relative political offences, i.e., such offence which contains elements of both common criminal and political corpus delicti.

The Swiss legal system invented predominance or proportional test. The Swiss courts' surrender, “only those fugitives whose acts were out of proportion to the political end sought or whose acts were not closely related with purely political ends [12]." 
Table 1.

\begin{tabular}{|l|l|l|}
\hline State of Origin & Name of the Test & The Nature of the Test \\
\hline Switzerland & Predominance or proportionality test & $\begin{array}{l}\text { The political offence shall be directly related to attaining the } \\
\text { political goal, and the political element of the action must } \\
\text { predominate over the criminal element or be proportioned to meet } \\
\text { the political objective. This test looks to the motivation of the } \\
\text { political offender and seeks to balance the objective with the } \\
\text { proportionality of violence. }\end{array}$ \\
\hline France & Objective test & $\begin{array}{l}\text { An offence is political only if the actor directly injures the state. } \\
\text { Regardless of the circumstances or the motivation of the potential } \\
\text { political offender, French courts only decide if the target is } \\
\text { substantially political in nature [13]. }\end{array}$ \\
\hline England & $\begin{array}{l}\text { There should be a political disturbance and the act should be part of } \\
\text { it. }\end{array}$ \\
\hline The United States & $\begin{array}{l}\text { Pelitical incidence test } \\
\text { incidence test'. of English 'political }\end{array}$ & $\begin{array}{l}\text { Any offence committed in the course of or furtherance of civil war, } \\
\text { insurrection, or political commotion }\end{array}$ \\
\hline Germany & 'Injured rights' test & $\begin{array}{l}\text { Political offences are crimes perpetrated with a political motivation } \\
\text { and directed against the existence and security of the State. }\end{array}$ \\
\hline
\end{tabular}

Dr. Christine Van den Wijngaert highlights that defining the political offence could become a challenging task as any crime could become a political based on the motives [14]. This approach seems to be appropriate, as some of the aforementioned tests excluded the motives and purposes of a crime that make such test highly narrow. Therefore, we shall agree with the approaches of Germany and Switzerland to the tests undertaken.

The Russian Federation legislation and practice In Russia, there is no special test in this regard. According to Article 2.2 of the Federal Law "About the Ratification of the European Extradition Convention", the notion of 'political offence' is not enshrined in Russian legislation.

The Russian Federation highlighted that it will not consider several crimes as 'political offences' or 'related political offences'. Such crimes are those enshrined in Article 1 of the Additional Protocol 1975 to the European Convention on Extradition that basically includes war crimes, genocide, and crimes against humanity. In addition, in the Federal Law, Russia added a list of non-political crimes that includes acts prohibited by the International Convention on the Suppression and Punishment of the Crime of Apartheid [15],Convention against Torture and Other Cruel, Inhuman or Degrading Treatment or Punishment [16], Convention for the Suppression of Unlawful Seizure of Aircraft [17] and several others [18].

Despite the absence of such test, there is a general rule in Russian criminal law that in the determination of corpus delicti, there is a determination of actus rea, mens rea, the object of a crime and the subject of a crime.

Mens rea or mental element includes consideration of, inter alia, motives, intent, and purposes. In regards of actus rea, there is a determination of modus operandi, the process of committing crime and other. Hence, we presume that the aforementioned are taken into account during determination of the political character of the crime.
Notwithstanding, there is no clear scenario and predominated factors that exist in other jurisdictions. The legislative definition of a 'political offence' is essential for two reasons: to protect human rights more effectively in extradition and asylum cases and to avoid the abuse of the right to political asylum. Currently, fugitives frequently claim that they are persecuted in a requesting state in order to prolong and delayed the process of the extradition. Despite the fact that right to asylum is of paramount importance and shall be considered by the authorities in the first place, this right is abused by some of the criminals.

The case of Mr. Baskakov is illustrative in these regards. Mr. Baskakov, while being on the territory of Russia, was prosecuted in Ukraine for committing grave bodily injuries. The General Prosecutor Office granted extradition. Mr. Baskakov and his lawyer were appealing the decision on extradition while at the same time applying for political asylum.

Mr. Baskakov did not provide the court with any evidences that he is prosecuted due to political reasons. The extradition requested was granted by Russia on November 1, 2010. The final cassation decision was made March 4, 2011. The case shows that a person without any single proof of a political persecution is capable of delaying the process for minimum 5 months [19].

Therefore, determination of the 'political offence' in the national or regional level could make the process easier, faster, more effective and efficient. The importance of the definition is not a purpose per se, it is rather a function that is necessary in order to conduct extradition.

\section{Summary}

The research question asks whether or not the political features of the extradition can be reduced or eliminated. It seems from the case-law presented that politics will always influence the law. The European Union came closer to the achievement of the goal. The main concept that invokes is the concept of mutual trust. However, the adoption of the same model for all states in the world seems to be a premature 
consideration. I shall agree with Charles de Visscher, who said: "law cannot be divorced from politics or power" [20] and admit that purely legal extradition without political involvement is a utopia [21]. Notwithstanding, the international community and national jurisdictions are capable of at least reduce the influence of the politics to the extradition. One of those steps is to establish the definition and common features of the 'political offence' clause.

\section{Conclusion}

The article sheds light on the possible steps to reduce the influence of the politics on the extradition. The paper present only one possible solution which is connected with the establishment of a clear political offence definition and determining test. We propose to undertake the German and Swiss approaches in this regard and consider the motives and consequences as of paramount importance. It shall be noted that the research is limited to the legal point of view while the topic is of a complex and interdisciplinary nature. Therefore, different approaches to the problem can be undertaken from different backgrounds such as social science, politics, international relations, negotiations and etc. The strong and detailed legal framework, nevertheless, is a basis for the improvement of the extradition process.

\section{Acknowledgement}

The work is performed according to the Russian Government Program of Competitive Growth of Kazan Federal University.

\section{References}

[1] Kapferer S.,Legal and Protection Policy Research Series: The Interface between Extradition and Asylum. - 2003 - United Nation High Commissioner for refugees, available at: http://www.unhcr.org/protect.

[2] Piontkovsky A.A.,Selected works. - Kazan - Kazan University, 2010.

[3] PriceM.E., Rethinking Asylum: History, Purpose, and Limits. - Vol. 35. - 2009, pp. 1-290.

[4] Historic Documents of 2013: Current Events that Chronicle the Year. -Los Angeles: CQ Press, an Imprint of SAGE Publications, Inc., 2014, pp.668.

[5, 14]Dr. Christine Van den Wijngaert,The Political Offence Exception to Extradition. The Netherlands: Kluwer, 1980, pp. 258.

$[6,12]$ Bedi S.D.,Extradition in International Law and Practice: Doctoral Thesis. - University of Utrecht; Rotterdam:Bronder-Offset, 1966, pp. 299.

[7,9] Africa B.,Political Offences in Extradition. Manila: Benipayo Press. - 1926 VII, pp. 161.
[8] Moore, Extradition. - Vol. I, 308: Fiore, 1891, pp. 327.

[10] Stephen J.F., History of Criminal Law in England. -Vol. II, Cambridge University Press, pp. 497.

[11] DeFabo V., Terrorist or Revolutionary: The Development of the Political Offender Exception and Its Effects on Defining Terrorism in International Law. - American University National Security Law Brief, Vol. 2, Issue 2, Article 5, 2012, pp. 69-104.

[13] Perry G.C., Comment, the Four Major Western Approaches to the Political Offence Exception to Extradition: From Inception to Modern Terrorism. - 40 Mercers, 1989, pp. 709-713.

[15] UN General Assembly, International Convention on the Suppression and Punishment of the Crime of Apartheid, $30 \quad$ November 1973, A/RES/3068(XXVIII), available at: http://www.refworld.org/docid/3ae6b3c00.html

[16] UN General Assembly, Convention Against Torture and Other Cruel, Inhuman or Degrading Treatment or Punishment, 10 December 1984, United Nations, Treaty Series, vol. 1465 , p. 85 , available at: http://www.refworld.org/docid/3ae6b3a94.html.

[17] United Nations, Convention for the Suppression of Unlawful Seizure of Aircraft, 16 December 1970, UN Treaty Series 1973, available at: http://www.refworld.org/docid/3ddcaa774.html.

[18] Federal law № 190-FZ 'About European Extradition Convention Ratification, October 25, 1999, available at: http://pravo.gov.ru/proxy/ips/\%3Fdoc_itself\%3D\%26 \%26nd\%3D102062477\%26\%26page\%3D1\%26rdk\%3 D0\#I0.

[19] Supreme Court of the Russian Federation, Cassational Ruling N 9-O11-5, March 4, 2011, available at: http://www.consultant.ru/.

[20] De Visscher C.,Theory and Reality in Public International Law. - Princeton Legacy Library, 2015, pp. 367.

[21] Shaw M.N., International Law. - Seventh Edition, Cambridge University Press, 2014, pp. 1064. 